Journal of Engineering and Applied Sciences 14 (20): 7700-7708, 2019

ISSN: 1816-949X

(C) Medwell Journals, 2019

\title{
A Study on the Street Parking and Occupancy in Makassar City (Case Study)
}

\author{
${ }^{1}$ Anugrah, ${ }^{2}$ Soemarno, ${ }^{3}$ Achmad Wicaksono and ${ }^{4}$ Lambang Basri \\ ${ }^{1}$ Department of Environmental Sciences and Development, \\ ${ }^{2}$ Department of Agriculture, \\ ${ }^{3}$ Department of Civil Engineering, Brawijaya University, Malang, East Java, Indonesia \\ ${ }^{4}$ Department of Civil Engineering, University of Muslim Indonesia, Makassar, \\ South Sulawesi, Indonesia anugrahyasin507@gmail.com
}

\begin{abstract}
In this study, we discuss the study of parking on Road Bodies in Makassar city. This study aims to determine parking conditions on four main roads selected by random purposive sampling, namely Somba Opu, Nusantara, Masjid Raya and Jenderal Sudirman Street. The data presented based on secondary data and and primary data which includes travel time data, vehicle speed, vehicle dimensions and number of vehicles used to analyze occupancy and occupancy percentage. The highest occupancy time on Somba Opu Street occurs on Wednesday at $06.00-10.00$ with the occupancy time of $260.00 \mathrm{sec}$, the highest occupancy time on Nusantara Street occurs on Wednesday 06.00-10.00 with vehicle occupancy time $260.00 \mathrm{sec}$. Along Masjid Raya Street within a week the highest occupancy time occurs on Thursday at 06.00-10.00 with a travel time of $230.00 \mathrm{sec}$. The occupancy time on Jendral Sudirman Street during the week of observation, namely the highest occupancy time is on Sunday at 16.00-18.00 with a travel time of $340.00 \mathrm{sec}$. The occupancy percentage on Somba Opu Street moves from $0.15-0.25 \%$ during the observation. Nusantara Street has an occupancy percentage all below $0.30 \%$. In addition, Wednesday shows the highest percent occupancy during the observation. On Masjid Raya Street between $0.17-0.30 \%$. The results of this study will be a material for decision makers of parking arrangements in the city of Makassar and other stakeholders as well as the community as road users.
\end{abstract}

Key words: On the street parking, vehicles, air pollution, occupancy, Makassar city, stakeholders

\section{INTRODUCTION}

The concept of development integrating ecological, economic and social aspects is referred to as sustainable development. The goal of sustainable development, according to the Law No. 4 of 1982 concerning the basic provisions of the environment which were perfected by Law No. 23 of 1997 focusing on environmental management can be achieved by management requirements. The environment must be in line with on harmonious and balanced environmental capabilities.

The population growth in Indonesia shows a very fast pace, especially, in urban areas. It has a very serious impact on decreasing of the environment supporting capacity. Moreover, the flow of urbanization which continues to increase impacts on the proportion of urban population to increase sharply. This is expected to continue, therefore, it is estimated that by 2025 , there will be (68.3\%) of Indonesia's population expected to inhabit cities (TTPS., 2010). The increasing population, especially, in urban areas is closely related to the increasing demand for housing, transportation and industrial activities. On the other hand, the supporting capacity of natural and environmental resources is very limited, so, the impact of development activities and all related movements often cause pollution to both land, water and air which ultimately leads to humans themselves as recipients of the consequences. Makassar city is no exception where Makassar city has a strategic position because it is located between the South and North in the South Sulawesi Region. Thus, the rapid growth of urbanization and industry in the region is inevitable for that Makassar becomes a mixed-commercial-residential-industrial area accompanied by an increasing number in the transportation sector which will cause other city problems namely air pollution including particles both coarse particles and fine particles (Sattar et al., 2012, 2014; Rashid et al., 2014). In another study, it was reported that Makassar city as one of the major cities in Eastern Indonesia has a relatively dense population and there is

Corresponding Author: Anugrah, Department of Environmental Sciences and Development, Brawijaya University, Malang, East Java, Indonesia, anugrahyasin507@gmail.com 
an increase in the population of productive age to find work and economic and business activities seen every year (Turyanti, 2011). Environmental conditions in the city have decreased both physical and chemical quality. One of them is waste of motor vehicle exhaust gas which pollutes the air, especially by $\mathrm{Pb}$, dust and $\mathrm{CO}$ (Al-Momani and Al-Nasser, 2011).

One characteristic of urban development in the transportation sector is the difficulty of finding available parking spaces which becomes problem in most major cities particularly in the city center including the city of Makassar. Vehicle parking spaces on the road side are alternatives that are worth considering. A study reported that the alternative could be done, especially when the population in urban areas increased and is expected to increase to $75 \%$ of the world population by 2050 (Bakici et al., 2013). Parking on the road is very limited and it is usually cheaper to find a free parking lot or pay and extend on the road side rather than wasting time (and fuel) in finding empty spaces for parking, especially in parking areas that have health consequences (Hertel et al., 2008). This is due to an increase in not only air pollution but also, driver stress condition. However, even paid space is now becoming rather difficult to find where city infrastructure has not grown in line with the population growth.

Some cities have tried to develop modern urban areas consisting of many elements and some of which have been subjected to intensive air pollution. Parking is an integrated part of modern city planning. In general, it is considered a very significant factor for planning and management of modern traffic systems (Hoglund, 2004; Neirotti et al., 2014). The prediction of parking availability is a subject that has been studied in the context of smart city, especially, now when most parking facilities install sensors as part of the infrastructures (Klappenecker et al., 2014).

Air pollution caused by the development of transportation systems is also, a phenomenon of transportation problems in the city of Makassar. Empirically, the number of motorized vehicles is increasing over time and in line with the level of population growth. This is due to the rapid growth rate of the number of vehicles and vehicle ownership, urbanization and the inefficient public transportation system which contributr to the increase of air pollution. This fact has an impact on the decrease in the level of environmental quality in the parking lot area on the streets of Makassar city. This problem is compounded by the presence of vehicles parked on the street (on street parking) and the position of parking vehicles which can increase the exhaust gas.
Several studies have reported the effect of parking activities on road bodies on the performance of roads in DKI Jakarta as well as the road bodies in Makassar city (Renta et al., 2012).

Along with that, it resulted in significant transportation problems. One of the transportation problems that need to be addressed is the problem of congestion on the main road sections and parking on the street as well as the position of parking vehicles that can increase the exhaust gas (Gautam, 2010). Parking on the street (on street parking) is caused by the increased vehicle ownership, limited resources and the lack of optimal operation of existing facilities such as parking lots (Abubakar, 2011). The emergence of parking on the road bodies scattered in several locations where there are no parking facilities, it has a negative impact on the traffic conditions, especially when the vehicle maneuvers out of the parking lot. Some of the main roads in Makassar city which are used for parking vehicles often cause new problems that are closely related to traffic flow and the surrounding environment that affect the level of comfort and safety of the community is decreasing due to disturbed aesthetic values (decreasing environmental quality).

Roadway parking arrangements make people feel disturbed and unhappy with the presence of on street parking because when people want to use or pass the road the journey becomes hampered. Parking on the road will be one of the factors that affect congestion, pollution, and there is no road parking deadline. However, many vehicle owners prefer to use the road body parking facilities as their parking lot because it is closer to where they want to go. Parking on the road is enough to cause public unrest in the city of Makassar. Parking lots are needed in the trade and service areas because people will temporarily entrust their vehicles until their interests are met. Until now, research related to parking on road bodies is still very lacking in Makassar city. Therefore, this study focuses on examining and looking at the actual parking conditions that occur on the road bodies which are used as parking spaces for vehicles. This study is an initial survey as an analysis of the possibility in applying the smart city concept in Makassar city.

\section{MATERIALS AND METHODS}

Study area: This research is about parking on the road body in the Makassar city area which causes congestion and air pollution in relation to environmental health. The location selection for the road is the parking area point in 


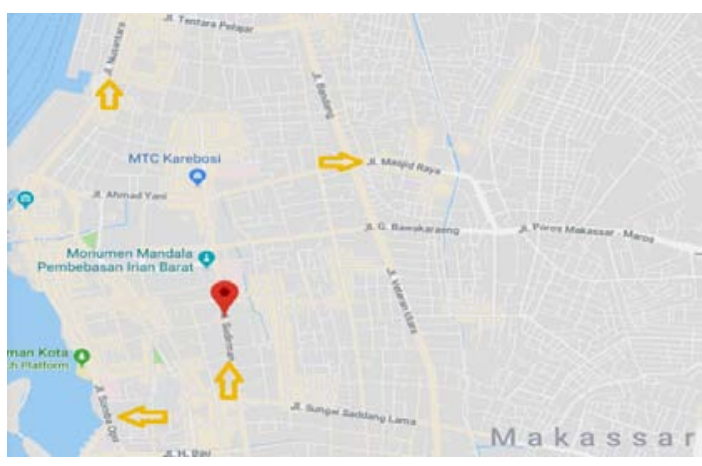

Fig. 1: Location of sampling sites in Makassar city

Makassar city which is determined purposively. The locations of this study are on the road in the center of Makassar, namely Somba Opu Street, Nusantara Street, Masjid Raya Street and Jenderal. Sudiman Street as shown in Fig. 1. The consideration in determining the location of parking for motorized vehicles on the road in the center of Makassar city includes:

- The observation point which is a protocol road and with a high level of traffic and parking

- The location of observation is also, the center of public activities such as trade, restaurants and means of public interest purposes

- The area with trade and service zoning interests explained in sub areas within Makassar city

\section{Data collection}

Primary data: Primary data obtained by survey and interview activities includes the data of:

- Preliminary data on road conditions in Makassar city

- Factual data about the condition of motorized vehicle parking lots from economical ecological and sociological aspects in sharing the road in Makassar city

- Factual data about the environmental conditions of the parking area in Makassar city

- Data on community social values

- Data on the economic values of the community

- Data on the direct and indirect benefits of the position of parking a motorized vehicle on the road body

- Data on ecological changes from the central area of road parking in Makassar city

Secondary data: Data obtained through documentation data on offices/agencies relating to research fields which include:
- Makassar city transportation data

- Data and results of the Makassar city KLHS

- Data generation and traffic movements in Makassar city

- Data on road infrastructure facilities in the city of Makassar

- Basic pattern data of traffic distribution, roads and number of parking in Makassar city

- Character data on the parking lot area in Makassar city

- Map of the use of the road body parking area

- Data on environmental changes in the parking center area in Makassar city

Data analysis: The data analysis used is descriptive analysis, namely by giving a description of the field data descriptively by interpreting the primary data into tabulations. This descriptive analysis aims to obtain an overview of the conditions and characteristics of the variables studied in each selected parking lot of the road (4 Roads). Then it is analyzed by occupancy analysis which includes calculation of travel time data, vehicle speed, vehicle dimensions, number of vehicles, occupancy time and parking area. Furthermore, percent occupancy is used to compare the four locations of the parking lot of the road used as a venue to collect data.

\section{RESULTS AND DISCUSSION}

One of the research objectives is to identify the effect of side barriers (road body parking) on motorized vehicles on various roads in the city of Makassar. The researcher selected four main roads in Makassar city with have similar characteristics and collected data on travel time, speed, number of vehicles, occupancy time and occupancy percentage of the vehicles. This step is needed to provide an overview of the average value of each variable before further examining the impact of these variable changes on the quality of motor vehicle exhaust gases. The results are as follows:

Travel time: Figure 2 shows the data on the average travel time of vehicles every day for a week taken from four roads in Makassar city. Based on these data, it can be seen that in general, the Light Vehicle (LV) or car has the longest average travel time compared to other motorized vehicles. The shortest travel time during observation is Heavy Vechicle (HV) or truck with a travel time of under $10 \mathrm{sec}$. This is because the truck stops at the point prepared by the business owner when entering the road in the observation. Meanwhile, Motor Cycle (MC) or motorcycle has a travel time of $<30 \mathrm{sec}$ when passing through the observation area. 


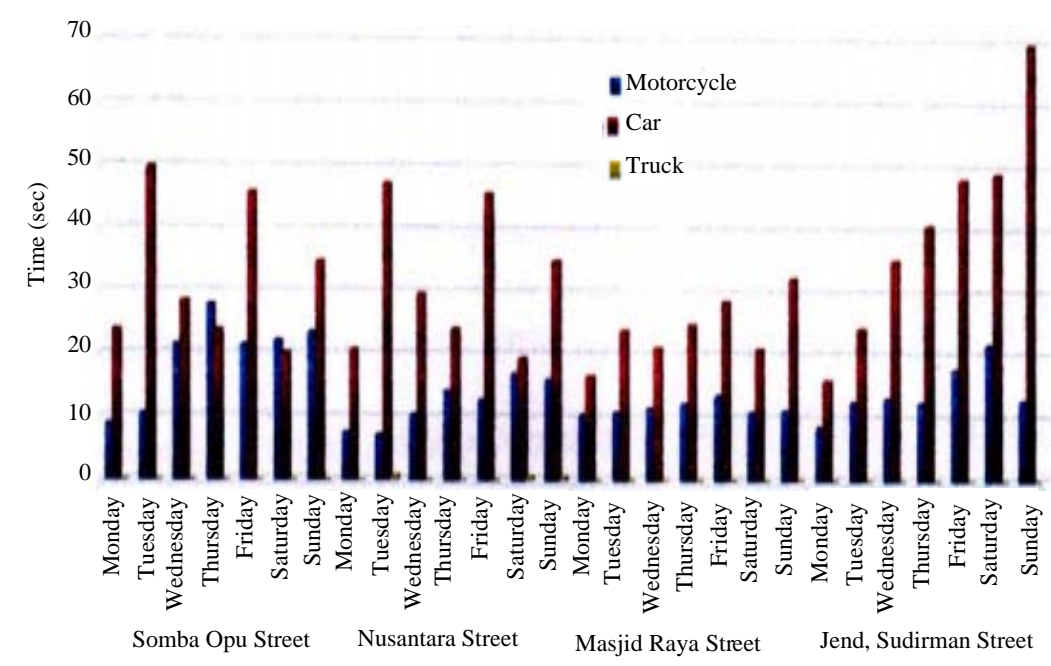

Fig. 2: Vehicle travel time

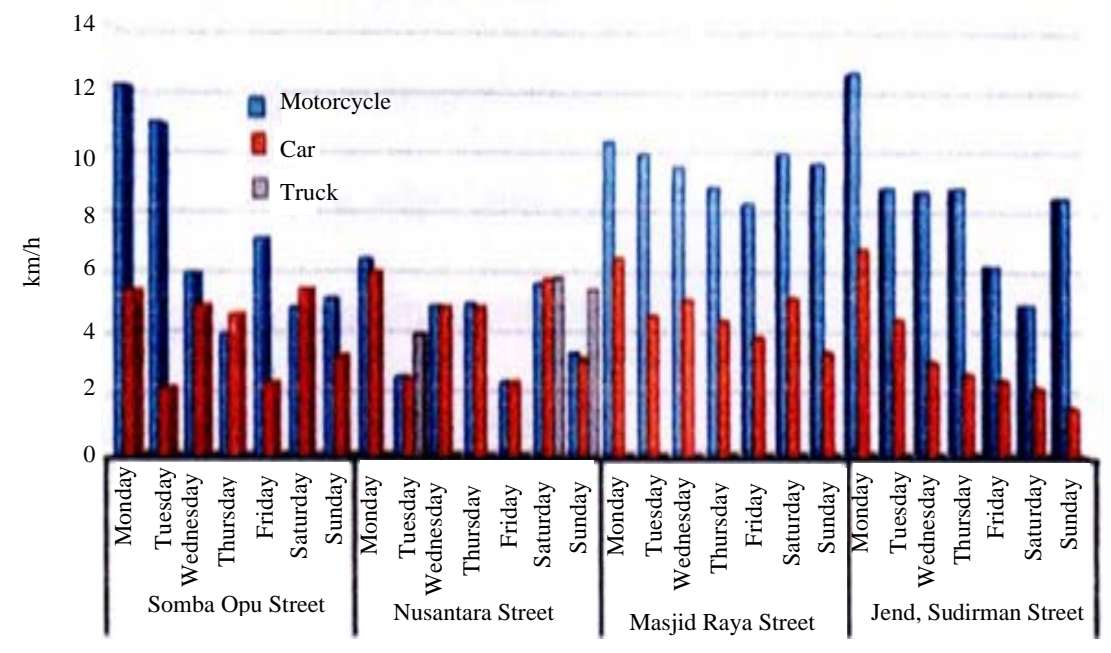

Fig. 3: Vehicle speed

The comparison of travel time (sec) between motorized vehicles on each road can be seen clearly. The car has the longest travel time on almost all observed roads, especially on Jenderal Sudirman Street on Sunday with a travel time of $70 \mathrm{sec}$. Meanwhile, the shortest travel time for a car takes place on Jenderal Sudirman Street on Monday with $15 \mathrm{sec}$. Motorbikes show the fastest travel time on Mondays and Tuesdays on Nusantara Street with a travel time of $<10 \mathrm{sec}$. While the longest motorcycle travel time is shown on Somba Opu Street on Thursday with a travel time of $28 \mathrm{sec}$. The results of data collection and analysis show that there are different travel times between vehicle types, road locations and observation days.

Vehicle speed: The following is a graph of the speed of the vehicle through various roads for 1 week:
Furthermore, Fig. 3 explains the average speed of the vehicle within a week. The results show that motor vehicles have an average speed faster in general than cars and trucks. It can be seen that car vehicles are at speeds below $8 \mathrm{~km} / \mathrm{h}$ compared to truck vehicles that only have speeds below $6 \mathrm{~km} / \mathrm{h}$ in a week.

Each vehicle has a different speed. On Jendral Sudirman Sudirman on Monday, the motor vehicles are at the highest speed when passing on four roads. Whereas on Saturday, Jendral Sudirman Street has only an average speed of $5 \mathrm{~km} / \mathrm{h}$ in a week. Unlike the car vehicle, Masjid Raya Street on Monday has a speed of $7 \mathrm{~km} / \mathrm{h}$ and on Sunday only has a speed of $3 \mathrm{~km} / \mathrm{h}$. However, trucks on Saturday have an average speed of $6 \mathrm{~km} / \mathrm{h}$ on Nusantara Street, compared to Friday only below $2 \mathrm{~km} / \mathrm{h}$. This is also, different on Somba Opu Street which has a much faster speed of $12 \mathrm{~km} / \mathrm{h}$ compared to Thursday at only $4 \mathrm{~km} / \mathrm{h}$. 


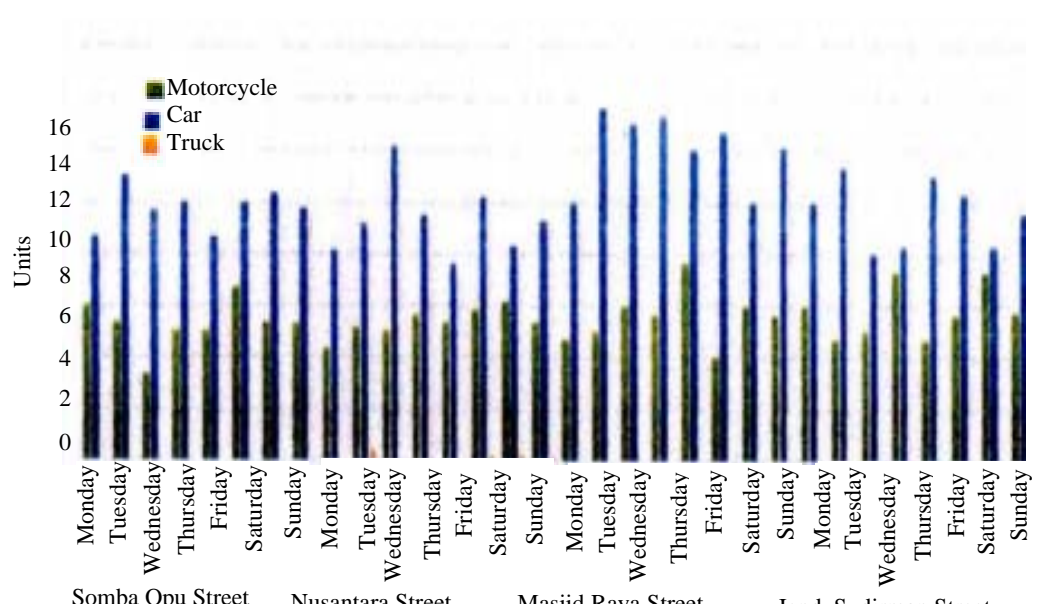

Fig. 4: Vehicle number

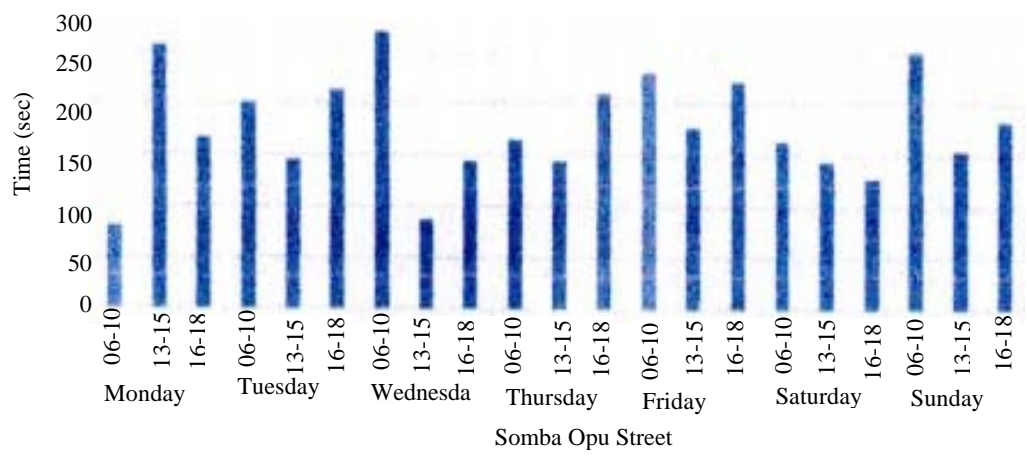

Fig. 5: Occupancy time on Somba Opu Street

With the above comparison on each trip, there are differences in the average speed in each vehicle. Based on this, it can be concluded that the highest average speed is in motorized vehicles traveling at each place, namely $13 \mathrm{~km} / \mathrm{h}$ on Jendral Sudirman Street. This is inversely proportional to the truck vehicles on Jendral Sudirman Sudirman where all of which are at an average speed below $2 \mathrm{~km} / \mathrm{h}$.

Vehicle number: Then in Fig. 4, it is explained that there are a number of vehicles passing in observation locations for a week. Observations on Somba Opu Street on Saturday showed that there were 7 vehicles passing by. This is many as on Wednesday only there were 300 motorbikes crossed Jalan Sombo Opu. Furthermore, the highest number of vehicle units on Jalan Nusantara is a car with 12 units passing. Whereas, on Friday only 7 units of motorcycles passed.

On Masjid Raya Street on Saturday only 400 motorbikes crossed, this was fairly small because on Friday there were as many as 7 units of motorbikes passing by. In line with that, Jendral Sudirman Street has also 7 motorbikes passing on Sunday. Unlike trucks, every week there are only 2 trucks passing on all road locations. This is inversely proportional when compared to motor vehicles and cars.

Having seen the difference in the number of vehicles passing in several locations, it can be concluded that the highest vehicle passing on Masjid Raya Street on Tuesday is 13 units of cars. When it compared to motorized vehicles on Sombo Opu Street on Wednesday, there were only 3 motorcycles passed.

\section{Occupancy time}

Somba Opu Street: Figure 5 shows the occupancy time on Somba Opu Street in a week. Through this picture, it can be seen that the highest occupancy time on Somba Opu Street occurs on Wednesday at 06-10 with occupancy time of $260 \mathrm{sec}$. While the lowest occupancy time is also, found on Wednesday at 13-15 with occupancy time of only $90 \mathrm{sec}$. This shows a quite high difference between occupancy time on Wednesday at 06-10 $\mathrm{h}$ and $13-15 \mathrm{~h}$.

Nusantara Street: After discussing the occupancy time on Somba Opu Street, then, Fig. 6 explains about 


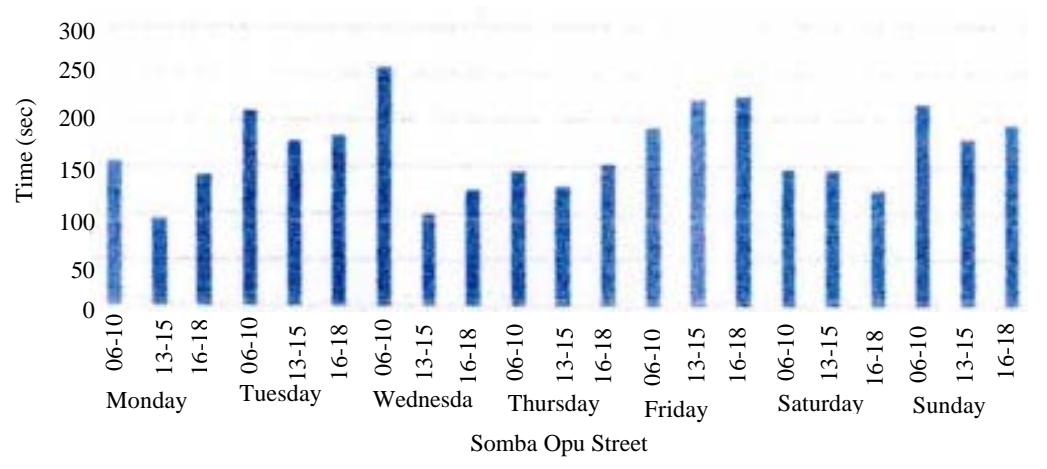

Fig. 6: Time occupancy on Nusantara Street

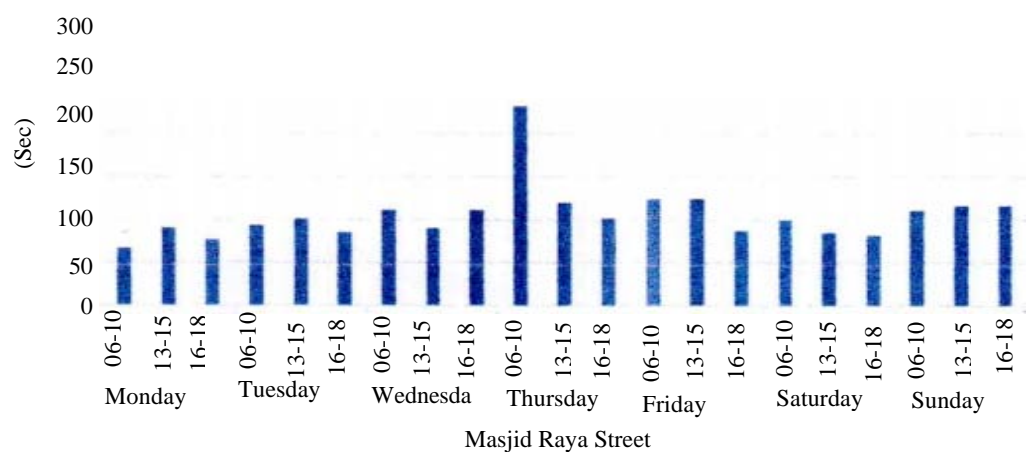

Fig. 7: Occupancy time on Masjid Raya Street

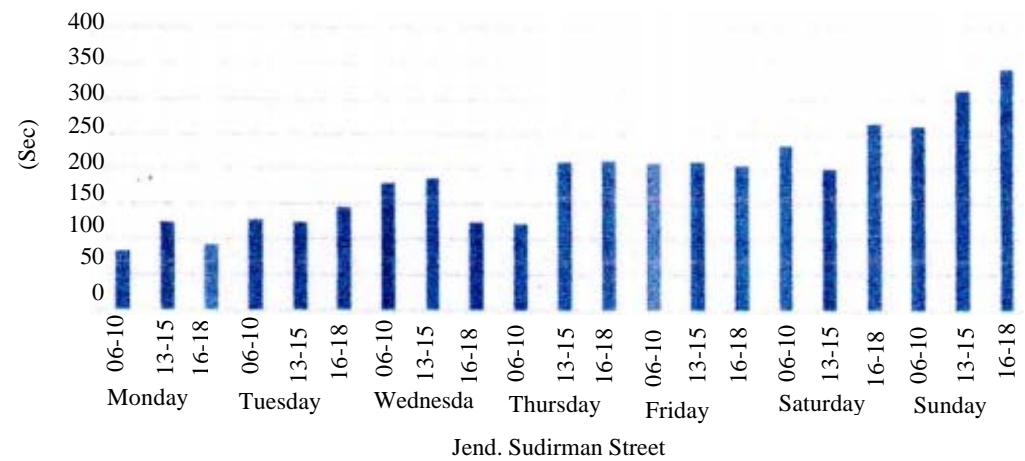

Fig. 8: Occupancy time on Jenderal Sudirman Street

occupancy time on Nusantara Street in a week. The highest occupancy time occurs on Wednesday at 06-10 with vehicle occupancy time $260 \mathrm{sec}$. The occupancy time that occurs on Monday at 13-15 has a travel time of only $90 \mathrm{sec}$. Based on the explanation, it can be concluded that the occupancy time on Nusantara Street has different occupancy times every day.

Masjid Raya Street: Figure 7 illustrates the occupancy time on Masjid Raya Street in a week. The highest occupancy time occurs on Thursday at 06-10 with a travel time of $230 \mathrm{sec}$. While others have an occupancy time of just under $130 \mathrm{sec}$. This has a quite high difference in occupancy time in a week on Masjid Raya Street.

Jenderal Sudirman Street: Figure 8 shows the occupancy time on Jendral Sudirman Street for a week of observation. The highest occupancy time is on Sunday at 16-18 with a travel time of $340 \mathrm{sec}$. While the lowest occupancy time is on Monday at 06-10 with only $90 \mathrm{sec}$. Conversely, on Friday all vehicles have the same occupancy time of $210 \mathrm{sec}$. The occupancy time on Jendral Sudirman Street tends to be higher on weekends (Saturday and Sunday) than other days. 


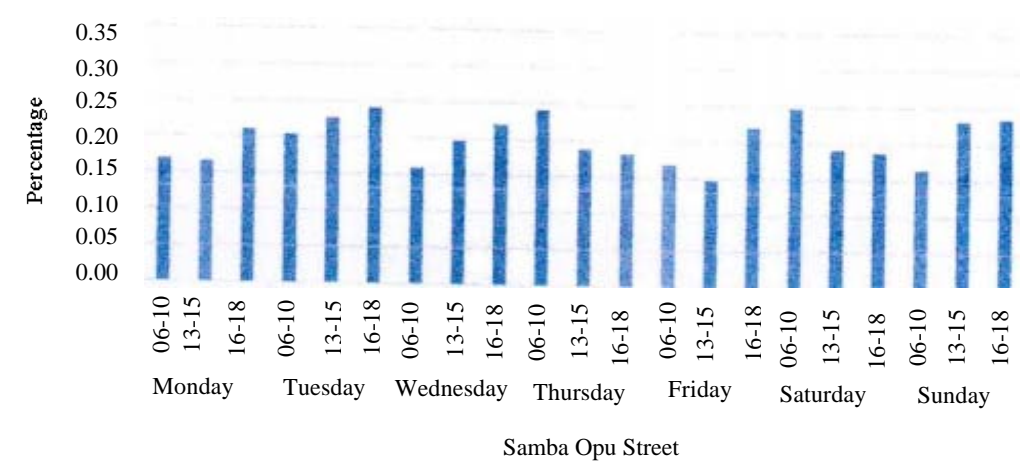

Fig. 9: Occupancy percentage on Somba Opu Street

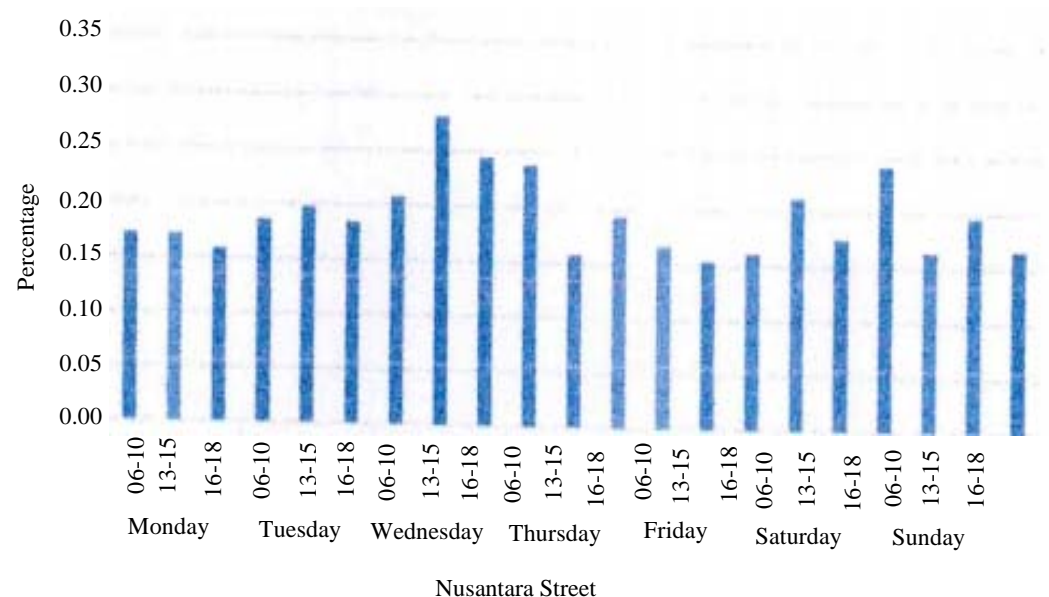

Fig. 10: Occupancy percentage on Nusantara Street

\section{Occupancy percentage}

Somba Opu Street: Figure 9 shows the occupancy percentage on Somba Opu Street. Saturday at 06-10 is the highest percentage of occupancy of vehicles at the observation location which reaches $0.25 \%$. While the percentage of the lowest occupancy of vehicles in the parking lot occurred on Friday at 13-15 which only reached $0.15 \%$. Based on the observation of percentoccupancy during the location on Somba

Opu Street can be understood that occupancy percentage moves from $0.15-0.25 \%$ during the observation.

Nusantara Street: After discussing the occupancy percentage on Somba Opu Street, then, Fig. 10 shows the occupancy percentage on Nusantara Street. The highest percentage of parking occupancy is on Wednesday at $13-15$ which reaches $0.28 \%$. Unlike on Friday at the same time which has a long percentage of vehicle parking only reached $0.15 \%$. This is fairly low, compared to the percentage of occupancy of the vehicle at other times of observation. Through this description, it can be seen that Nusantara Street has a percentage of occupancy time below $0.30 \%$. In addition, Wednesday shows the highest percent occupancy during the observation conducted.

Mesjid Raya Street: Figure 11 explains the occupancy percentage on Masjid Raya Street. It can be seen that on Tuesday at 13-15 and Wednesday at 13-15 the percentage of vehicles parked reached $0.30 \%$. This also happened on Sunday at 13-15 and 16-18 the percentage of parked vehicles also reached $0.17 \%$. However, unlike Monday at 06-10 the percentage of vehicle parking reached $0.18 \%$. The description can conclude that occupancy percentage has a difference and the same percentage of the length of the vehicle parked on Masjid Raya Street.

Jenderal Sudirman Street: Figure 12 explains the occupancy percentage on Jendral Sudirman Street in a week. On Wednesday at 16-18 the percentage of vehicles parked is only $0.15 \%$. This is relatively low, when compared to the highest percentage that occurs on Saturdays at $06-10$, reaching $0.30 \%$. Therefore, through the graph image, it can be concluded that the occupancy percentage on Jenderal Sudirman Street 


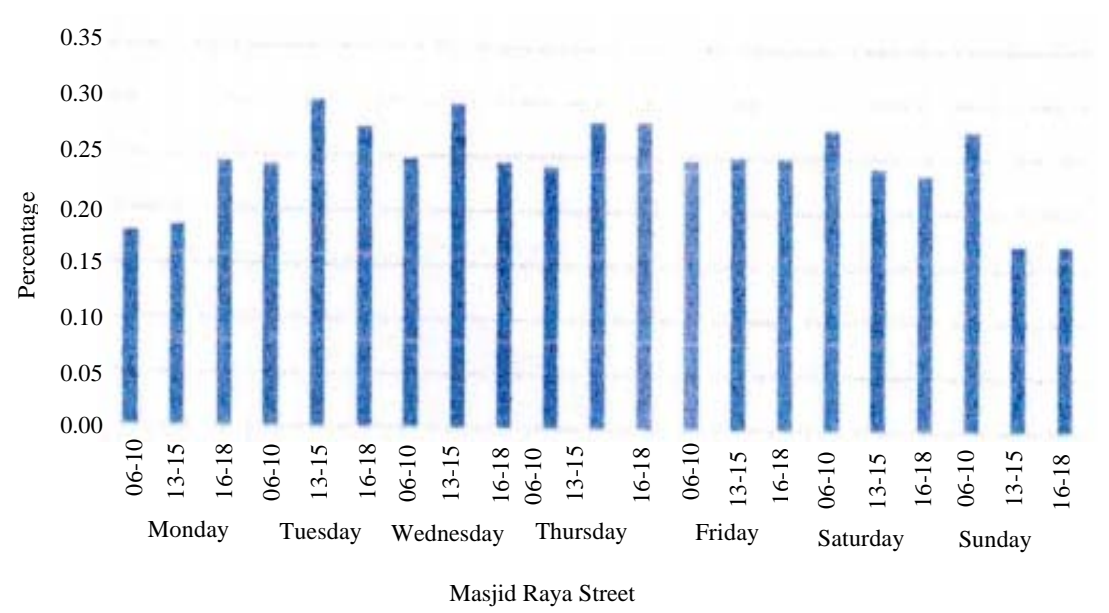

Fig. 11: Occupancy percentage on Mesjid Raya Street

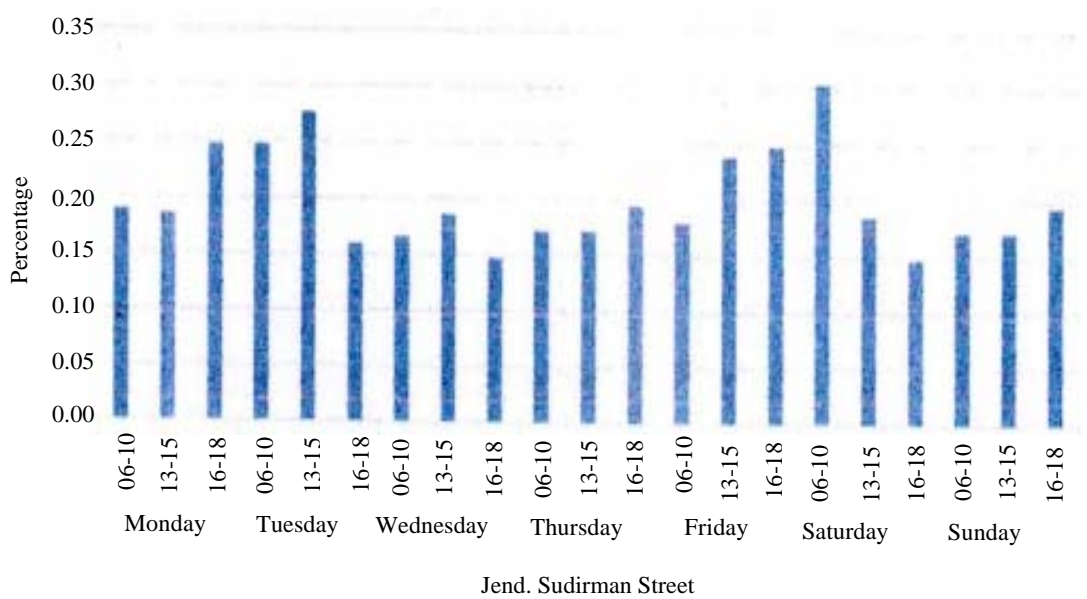

Fig. 12: Occupancy percentage on Jenderal Sudirman Street

has a difference in the length of the vehicle in the lowest and highest parking lot and some also have similarities. Mondays, Tuesdays and Saturdays tend to show a higher percentage of occupancy than the other days.

\section{CONCLUSION}

One week's observations concluded that the car had the longest average travel time compared to other motorized vehicles. The shortest travel time during observation is Heavy Vechicle (HV) or truck with a travel time of under $10 \mathrm{sec}$. Motorcycle vehicles have an average speed faster than cars and trucks. It can be observed that the average speed of motor vehicles traveling at each place is $13 \mathrm{~km} / \mathrm{h}$ while car vehicles are at speeds below $8 \mathrm{~km} / \mathrm{h}$ and truck vehicles that only have speeds below $6 \mathrm{~km} / \mathrm{h}$. As for the average number of vehicles passing in several locations, the location of the most vehicles that pass through is on Masjid Raya Street on Tuesday which is 13 car units when compared to
Somba Opu, Nusantara and Jenderal Sudirman Streets. Somba Opu Street on Wednesday only saw 300 motorbikes are passing. The highest occupancy time on Somba Opu Street occurs on Wednesday at 06-10 with occupancy time of $260 \mathrm{sec}$, the highest occupancy time on Nusantara Street occurs on Wednesday 06-10 with vehicle occupancy time $260 \mathrm{sec}$. Along Masjid Raya Street within a week, the highest occupancy time occurs on Thursday at $06-10$ with a travel time of $230 \mathrm{sec}$. The occupancy time on Jendral Sudirman Street during the week of observation, namely the highest occupancy time is on Sunday at $16-18$ with a travel time of $340 \mathrm{sec}$. The occupancy percentage on Somba Opu Street moves from $0.15-0.25 \%$ during observation. Nusantara Street has a percentage of occupancy all below $0.30 \%$. In addition, Wednesday shows the highest percentage of occupancy during the observation. On Masjid Raya Street there are between $0.17-0.30 \%$. The other days other than Saturday at $06-10(0.30 \%)$ lower in occupancy pecentage. 


\section{ACKNOWLEDGEMENT}

This research activity was carried out with the permission and support from the South Sulawesi Provincial Government, more specifically, the South Sulawesi Provincial Education Office, Makassar City Government. Therefore, we express our highest gratitude and appreciation.

\section{REFERENCES}

Abubakar, I., 2011. [Parking: Introduction to Planning and Organizing Parking Facilities]. Transindo Gastama Media, Jakarta, Indonesia, ISBN:9786029550719, (In Indonesian).

Al-Momani, T. and A.D. Al-Nasser, 2011. Emission rate of gases emitted from private gasoline vehicles in Irbid-Jordan. Jordan J. Civil Eng., 5: 287-301.

Bakici, T., E. Almirall and J. Wareham, 2013. A smart city initiative: The case of Barcelona. J. Knowl. Econ., 4: 135-148.

Gautam, S.P., 2010. Study of the exhaust gases from different fuel based vehicles for carbonyls and methane emissions. Central Pollution Control Board, Bengaluru, India. http:/www. india environment portal. org.in/content $/ 321825 /$ study-of-the-exhaustgases-from-different-fuel-based-vehicles-for-carbo nyls-and-methane-emissions.

Hertel, O., S.S. Jensen, M. Hvidberg, M. Ketzeln and R. Berkowicz et al., 2008. Assessing the Impacts of Traffic Air Pollution on Human Exposure and Health. In: Road Pricing, the Economy and the Environment, Jensen-Butler, C., B. Sloth, M.M. Larsen, B. Madsen and O.A. Nielsen (Eds.). Springer, Berlin, Germany, ISBN:9783540771500, pp: 277-299.
Hoglund, P.G., 2004. Parking, energy consumption and air pollution. Sci. Total Environ., 334: 39-45.

Klappenecker, A., H. Lee and J.L. Welch, 2014. Finding available parking spaces made easy. Ad Hoc Networks, 12: 243-249.

Neirotti, P., A. De Marco, A.C. Cagliano, G. Mangano and F. Scorrano, 2014. Current trends in smart city initiatives: Some stylised facts. Cities, 38: 25-36.

Rashid, M., S. Yunus, R. Mat, S. Baharun and P. Lestari, 2014. PM10 black carbon and ionic species concentration of urban atmosphere in Makassar of South Sulawesi Province, Indonesia. Atmos. Pollut. Res., 5: 610-615.

Renta, I., M.I. Ramli, S.H. Aly and L. Samang, 2012. A study on the effect of on-street parking of the school activity on the vehicle speed in an Urban road. Proceedings of the 15th FSTPT International Symposium on STTD, November 23-24, 2012, STTD Bekasi, Java, Indonesia, pp: 1-11.

Sattar, A., M. Rashid, R. Mat and L. Puji, 2012. A preliminary survey of air quality in Makassar city South Sulawesi Indonesia. J. Teknol., 57: 123-136.

Sattar, Y., M. Rashid, M. Ramli and B. Sabariah, 2014. Black carbon and elemental concentration of ambient particulate matter in Makassar Indonesia. IOP. Conf. Ser. Earth Environ. Sci., 18: 1-7.

TTPS., 2010. [The Guide Book for Community Empowerment with Gender Engagement and Poverty in City Sanitation Development]. Badan Perencanaan Pembangunan Nasional, Central Jakarta, Indonesia, (In Indonesian).

Turyanti, A., 2011. [Cities of satellite and urban air quality]. Master Thesis, Institut Pertanian Bogor, Bogor Agricultural University, Bogor, Indonesia. (In Indonesian). 